\title{
Unmasking Proteolytic Activity for Adult Visual Cortex Plasticity by the Removal of Lynx 1
}

\author{
Noreen Bukhari, ${ }^{1,2,3,4,5}$ Poromendro N. Burman, ${ }^{1,2,3,4,5}$ Ayan Hussein, $, 1,2,3,4,5$ Michael P. Demars, ${ }^{1,2,3,4,5}$ \\ Masato Sadahiro, ${ }^{1,2,3,4,5}$-Daniel M. Brady, ${ }^{6}$ Stella E. Tsirka, ${ }^{7}$ Scott J. Russo, ${ }^{2,5}$ and Hirofumi Morishita ${ }^{1,2,3,4,5}$ \\ Departments of ${ }^{1}$ Psychiatry, ${ }^{2}$ Neuroscience, and ${ }^{3}$ Ophthalmology, ${ }^{4}$ Mindich Child Health and Development Institute, and ${ }^{5}$ Friedman Brain Institute, Icahn \\ School of Medicine at Mount Sinai, New York, New York 10029, ${ }^{6}$ Department of Physiology, University of California at San Francisco, San Francisco, \\ California 94143, and 7 Department of Pharmacological Sciences, Stony Brook University, Stony Brook, New York 11794
}

Experience-dependent cortical plasticity declines with age. At the molecular level, experience-dependent proteolytic activity of tissue plasminogen activator (tPA) becomes restricted in the adult brain if mice are raised in standard cages. Understanding the mechanism for the loss of permissive proteolytic activity is therefore a key link for improving function in adult brains. Using the mouse primary visual cortex (V1) as a model, we demonstrate that tPA activity in V1 can be unmasked following $4 \mathrm{~d}$ of monocular deprivation when the mice older than 2 months are raised in standard cages by the genetic removal of Lynx1, a negative regulator of adult plasticity. This was also associated with the reduction of stubby and thin spine density and enhancement of ocular dominance shift in adult V1 of Lynx1 knock-out (KO) mice. These structural and functional changes were tPA-dependent because genetic removal of tPA in Lynx1 K0 mice can block the monocular deprivation-dependent reduction of dendritic spine density, whereas both genetic and adult specific inhibition of tPA activity can ablate the ocular dominance shift in Lynx1 K0 mice. Our work demonstrates that the adult brain has an intrinsic potential for experience-dependent elevation of proteolytic activity to express juvenile-like structural and functional changes but is effectively limited by Lynx 1 if mice are raised in standard cages. Insights into the Lynx1-tPA plasticity mechanism may provide novel therapeutic targets for adult brain disorders.

Key words: Lynx1; ocular dominance; plasticity; spine; tPA; visual cortex

\section{Significance Statement}

Experience-dependent proteolytic activity of tissue plasminogen activator (tPA) becomes restricted in the adult brain in correlation with the decline in cortical plasticity when mice are raised in standard cages. We demonstrated that removal of Lynx1, one of negative regulators of plasticity, unmasks experience-dependent tPA elevation in visual cortex of adult mice reared in standard cages. This proteolytic elevation facilitated dendritic spine reduction and ocular dominance plasticity in adult visual cortex. This is the first demonstration of adult brain to retain the intrinsic capacity to elevate tPA in an experience-dependent manner but is effectively limited by Lynx1. tPA-Lynx1 may potentially be a new candidate mechanism for interventions that were shown to activate plasticity in adult brain.

\section{Introduction}

Experience-dependent brain plasticity becomes restricted in adulthood (Wiesel, 1982; Hensch, 2004; Knudsen, 2004). A cen-

Received 0ct. 17, 2014; revised July 30, 2015; accepted Aug. 4, 2015.

Author contributions: N.B., S.E.T., S.J.R., and H.M. designed research; N.B., P.N.B., A.H., M.P.D., M.S., and H.M. performed research; D.M.B. contributed unpublished reagents/analytic tools; N.B., P.N.B., A.H., M.P.D., M.S., and H.M. analyzed data; N.B. and H.M. wrote the paper.

This work was supported by National Eye Institute R01EY024918 to H.M., National Institute of Neurological Disorders and Stroke 5T32NS551147-5 to N.B., National Institute on Drug Abuse T32 DA007135 to M.P.D., National Institute of Mental Health T32MH096678 to M.S., National Institute of General Medical Sciences R25GM064118 to A.H., Knights Templar Eye Foundation to H.M., March of Dimes to H.M., Whitehall Foundation to H.M., and Brain and Behavior Research Foundation to H.M. We thank Drs. Dan Christoffel and Sam Golden (Icahn School of Medicine at Mount Sinai) for providing technical expertise on spine analysis; Dr. Rachel Neve (Massachusetts Institute of Tech- tral issue is that this limits recovery of function for brain disorders later in life. Successful therapies are therefore contingent on understanding the mechanism limiting adult brain plasticity (Mitchell and Sengpiel, 2009; Bavelier et al., 2010).

The rodent visual system is a well-defined model to study the mechanism restricting experience-dependent plasticity in the

nology) for supplying HSV-GFP; and Dr. Nathaniel Heintz (Rockefeller University) for providing Lynx1 knock-out mice.

The authors declare no competing financial interests.

Correspondence should be addressed to Dr. Hirofumi Morishita, Icahn School of Medicine at Mount Sinai, One Gustave L. Levy Place, Box 1230, New York, NY 10029. E-mail: hirofumi.morishita@mssm.edu.

DOI:10.1523/JNEUROSCI.4315-14.2015

Copyright $\odot 2015$ the authors $\quad 0270-6474 / 15 / 3512693-10 \$ 15.00 / 0$ 
adult (Morishita and Hensch, 2008; Espinosa and Stryker, 2012; Levelt and Hübener, 2012; Hübener and Bonhoeffer, 2014). During the juvenile critical period, short-term monocular deprivation (MD) produces robust functional and structural plasticity; a shift in ocular dominance (OD) of V1 neurons in favor of the open eye measured electrophysiologically (Fagiolini et al., 1994; Gordon and Stryker, 1996), and the elevated motility and reduction of dendritic spines (Mataga et al., 2004; Oray et al., 2004). Importantly, such juvenile forms of plasticity become limited in adult V1 under standard housing conditions.

However, OD plasticity can be either reactivated or preserved even in the adult with additional environmental, such as dark exposure (He et al., 2006, 2007; Duffy and Mitchell, 2013; Stodieck et al., 2014), environmental enrichment (Sale et al., 2007; Greifzu et al., 2014), visual stimulation (Matthies et al., 2013), sensory-motor interaction (Kaneko and Stryker, 2014; Fu et al., 2015), voluntary physical exercise (Kalogeraki et al., 2014), and social experience (Balog et al., 2014) in addition to pharmacological interventions (Putignano et al., 2007; Maya Vetencourt et al., 2008; Morishita et al., 2010; Nabel and Morishita, 2013), suggesting the intrinsic potential of the adult brain to unmask plasticity. Although there is significant progress in determining the underlying neural mechanisms of interventions, such as reduced intracortical inhibition (Greifzu et al., 2014; Stodieck et al., 2014), disinhibitory cortical circuit (Fu et al., 2015), and serotonin (Matthies et al., 2013), it is essential to keep uncovering molecular bases of such intrinsic potential of adult $\mathrm{V} 1$ to promote plasticity and understand how such potentials can be unmasked in adult V1.

One of the few permissive molecular pathways known to reflect the decline of experience-dependent plasticity with age is of tissue plasminogen activator (tPA), a major serine protease in the brain. MD during the critical period results in elevated tPA activity, whereas MD in adult mice shows no change in TPA activity if mice are raised in standard cages (Mataga et al., 2002, 2004). Genetic removal of tPA results in a loss of OD and spine plasticity during critical period (Mataga et al., 2004; Oray et al., 2004), suggesting that tPA is one of the major molecular factors corresponding to structural and functional plasticity during juvenile period but not adulthood. The aim of our study was to understand why experience-dependent elevation of tPA and associated structural and functional plasticity becomes limited in the adult brain $>2$ months raised in mice raised in standard cages and how it can be activated in the adult mice brain under these conditions.

We previously showed that Lynx1, an inhibitor of nicotinic acetylcholine receptors (Miwa et al., 1999) is a molecular inhibitor of OD plasticity that increases into adulthood when experience-dependent elevation of tPA is reciprocally lost. Genetic removal of this molecular inhibitor unmasks OD plasticity in the adult brain (Morishita et al., 2010), but the molecular and structural underpinnings remain unclear. We thus hypothesized that the adult brain has an intrinsic potential for experiencedependent tPA elevation but is effectively masked by Lynx 1 if mice are raised in standard cages. We found that the removal of this molecular brake unlocks the proteolytic activity, which is necessary for the juvenile form of structural and functional plasticity in the adult brain. Our study demonstrates the central role of experience-dependent elevation of tPA activity in restoring adult brain plasticity.

\section{Materials and Methods}

Animals. A total of 77 males and 49 females C57BL/6 (Charles River Laboratory, The Jackson Laboratory), Lynx1 KO (gifted by Dr. Nathaniel Heintz: Rockefeller University) (Miwa et al., 2006), and Lynx1-tPA Dou- ble Knock-out (DKO) mice (tPA KO mice were originally purchased from The Jackson Laboratory \#002508, backcrossed to C57BL/6 for 12 generations by S.T. and transferred to H.M.) (Carmeliet et al., 1994) were used at postnatal age 53-392 d (1.7-13.1 months) (averages and ranges of ages of mice for each experimental groups are described in figure legends). Both male and female were used (details of each experimental groups are described in figure legends). All mice were housed in groups of $2-5$ together with the sibling groups of the same sex in standard and uniform cage sizes $(199 \mathrm{~mm} \times 391 \mathrm{~mm} \times 160 \mathrm{~mm}$ : width $\times$ depth $\times$ height, GM500, Tecniplast) and maintained on a $12 \mathrm{~h} \mathrm{light/dark} \mathrm{cycle}$ with ad libitum access to food and water. Mouse procedures were performed in accordance with the Institutional Animal Care and Use Committee guidelines of the Icahn School of Medicine at Mount Sinai.

$M D$. Adult mice $(>\mathrm{p} 60)$ were anesthetized with isoflurane. Eyelid margins were trimmed by iris scissor and eyes sutured shut for $4 \mathrm{~d}$. After preforming $\mathrm{MD}$, mice were returned to their home cages until the time of death.

Stereotaxic surgery and viral gene transfer. Mice were anesthetized with isoflurane and positioned in a small-animal stereotaxic instrument (Narishige). For the dendritic spine analysis, a 30 gauge syringe needle (Hamilton) was used to infuse $0.5 \mu$ l of Herpes simplex virus expressing green fluorescent protein (HSV-GFP provided by Dr. Rachel Neve, Massachusetts Institute of Technology: $1.5 \AA 108$ infectious units $/ \mathrm{ml}$ ) into the binocular zone of right V1 (lamda coordinates: anteroposterior 0 $\mathrm{mm}$; mediolateral $3.0 \mathrm{~mm}$; dorsoventral $0.2 \mathrm{~mm}$ ) at a rate of $0.1 \mu \mathrm{l} / \mathrm{min}$ $3 \mathrm{~d}$ before perfusion. For tPA serpin injections, $21 \mathrm{~d}$ before MD, Lynx1 KO mice were infused with either (1) adeno-associated virus (AAV)-GFP (a mixture of AAV8-hSyn-cre-mcherry, UNC core: $3 \times 10^{12} \mathrm{IU} / \mathrm{ml}$; plus AAV8-Ef1a-DIO-EGFP, UNC core: $8 \times 10^{12} \mathrm{IU} / \mathrm{ml}$ ) or (2) AAV-tPA serpin (a mixture of AAV8-hSyn-cre-mcherry plus AAV8-Efla-DIOEGFP-2A-tPA serpinil, UNC core: $2.9 \times 10^{12} \mathrm{IU} / \mathrm{ml}$ ) in right $\mathrm{V} 1$ at 600 $\mathrm{nl} /$ injection $\times 3$ injections (lamda coordinates: (1) anteroposterior: 0.0 $\mathrm{mm}$; mediolateral: $3.1 \mathrm{~mm}$; dorsoventral: $0.4 \mathrm{~mm}$; (2) anteroposterior: $0.0 \mathrm{~mm}$; mediolateral: $2.85 \mathrm{~mm}$; dorsoventral: $0.4 \mathrm{~mm}$; (3) anteroposterior: $0.3 \mathrm{~mm}$; mediolateral: $3.0 \mathrm{~mm}$; dorsoventral: $0.4 \mathrm{~mm}$ ) for total 1.8 $\mu \mathrm{l}$ injection/mouse.

Perfusion and tissue processing. After $4 \mathrm{~d}$ of $\mathrm{MD}$, mice were anesthetized with pentobarbital and transcardially perfused with PFA, postfixed with $\mathrm{PFA}$, and cryoprotected with sucrose/PBS. Brains were coronally sectioned ( $7 \mu \mathrm{m}$ in situ hybridization (ISH), $35 \mu \mathrm{m}$ for immunohistochemistry, $150 \mu \mathrm{m}$ for spine imaging). Brains injected with AAVs were directly mounted on slides using Vectashield (Vector Laboratories) mounting medium and coverslipped before imaging. For amidolytic assay, mouse V1 (2 $\mathrm{mm} \times 2 \mathrm{~mm}$ ) was isolated, flash frozen, and stored at $-80 \mathrm{C}$.

Generation and validation of $A A V-t P A$ serpin. cDNA of $t P A$ serpin (Serpini1) was amplified from cDNA library generated from mouse WT V1, placed in vector pcDNA3.1 (-) via Gibson assembly (New England Biolabs), and Escherichia coli transformed. Positive colonies were confirmed by sequencing (Genewiz). Vectors were then isolated by Midiprep (QIAGEN) and plasmid expression checked by transfection of N2A cells. To create pAAV vector, an inverted bicistronic $2 \mathrm{~A}$ sequence was inserted into pAAV-Efla-DIO-EGFP-WPRE-pA (Addgene, \#37084) upstream of EGFP by PCR linearization and overhang production on pAAV vector. TPA serpin pcDNA3.1 (-) vector was used as a template to produce tPA serpin, which was inserted into pAAV vector using Gibson assembly, transformation, restriction digest, and gene sequence as above. Following colony verification, Maxiprep was performed (QIAGEN, Maxi kit) and the amplified pAAV-Efla-DIO-EGFP-2A-tPA serpin-WPRE-pA plasmid was sent to the UNC viral core for viral packaging. To confirm viral efficiency, tPA serpin and EGFP RNA probes were synthesized using T3/T7 RNA polymerase (Roche) labeled with fluorescein. To perform ISH, sections were fixed with 4\% PFA and tPA serpin-fluorescein and EGFP-digoxigenin probes were hybridized to frozen sections overnight at $72^{\circ} \mathrm{C}$. To amplify the signal, probes were detected using antidigoxigenin or fluorescein antibody conjugated to alkaline phosphatase (Roche), or the TSA-Plus DNP System (PerkinElmer Life Sciences) in combination with fast red staining. Images were acquired using a fluorescent microscope and quantified with ImageJ (National Institutes of Health). 
Amidolytic assay. Isolated mouse V1 that includes the binocular zone $(2 \mathrm{~mm} \times 2 \mathrm{~mm})$ was homogenized in Tris-buffered saline, $\mathrm{pH}$ 7.0. Samples were centrifuged at $20,800 \times g$ for $15 \mathrm{~min}$ at $4^{\circ} \mathrm{C}$ and supernatant isolated. Brain homogenates were incubated with $0.19 \mu \mathrm{M}$ plasminogen, $10 \mathrm{~nm}$ fibrinogen in a $50 \mathrm{~mm}$ Tris buffer, $\mathrm{pH} 7.4$, with $2 \% \mathrm{BSA}$ and $0.3 \mathrm{~mm}$ chromogenic substrate-2251 (DiaPharma) at $37^{\circ} \mathrm{C}$. Cleavage of the chromogenic substrate $\mathrm{S}-2251$ by serine protease-generated plasmin and the subsequent color change was quantified at $405 \mathrm{~nm}$. A dose-response for pure recombinant tPA activity was run in parallel alongside the test samples and the time point when $R^{2}$ value for the dose-response $\sim 1$ was used to measure the concentration of serine protease in the samples. All samples were run in triplicates. Recombinant tPA Serpin protein $(90 \mathrm{~nm}$ Serpinil-2485M: creative biomart) was used to block tPA in the indicated samples.

Dendritic spine imaging and analysis. HSV-GFP-injected brain sections were blocked with $10 \%$ goat serum/PBS for $1 \mathrm{~h}$ at room temperature (RT), then incubated overnight in rabbit anti-GFP (Invitrogen, 1:1000) at RT, washed in PBS multiple times, followed by secondary antibody in rabbit anti-Alexa-488 (Invitrogen, 1/5000) for $4 \mathrm{~h}$ at RT. Sections were then washed multiple times in PBS and dehydrated in successively increased ethanol concentrations (75\%, 95\%, 100\%), and then Citrasolvent. Sections were mounted on Superfrost Plus slides using Permount (Sigma) mounting medium and coverslipped. Images were acquired on a confocal LSM 710 (Carl Zeiss). Apical dendrites from V1 neurons with soma in layer II/III were selected. To qualify for spine analysis, dendritic segments had to satisfy the following requirements: (1) the segment had to be completely filled (all endings were excluded); (2) the dendritic segment had to be $<200 \mu \mathrm{m}$ from the surface of V1; and (3) the segment could not be overlapping with other dendritic branches (Christoffel et al., 2011; Golden and Russo, 2012). Dendritic segments were imaged using a $100 \times$ lens (numerical aperture 1.4; Carl Zeiss) and a zoom of 3.0. Pixel size was $0.03 \mu \mathrm{m}$ in the $x-y$ plane and $0.01 \mu \mathrm{m}$ in the $z$ plane. Images were taken with a resolution of $1024 \AA \times 300$, pixel dwell time was $1.58 \mu \mathrm{m} / \mathrm{s}$, and the line average was set to 8 . An average of 75 dendritic spines per group ( $n=31$ mice, $n=4-6$ mice per group) totaling $\sim 460$ dendritic spines were analyzed. Images were deconvolved using a two step resolution enhancement: first with AutoDeblur software (Media Cybernetics) and then by $z$-smear correction in Neuron-Studio (Rodriguez et al., 2006; Dumitriu et al., 2011). For quantification, Neuron-Studio was used to classify spines as thin, mushroom, or stubby based on the following values: (1) aspect ratio, (2) head to neck ratio, and (3) head diameter. Spines with a neck can be classified as either thin or mushroom, and those without a significant neck are classified as stubby. Spines with a neck are labeled as thin or mushroom based on head diameter (Rodriguez et al., 2006, 2008). Spine density = total spine count/dendritic length. All measurements were made with an observer blinded to the genotype of the mice.

In vivo extracellular recording. Recording was performed under Nembutal/chlorprothixene anesthesia. Briefly, visually evoked single-unit responses were recorded with 16 channel silicone probes (Neuronexus) in response to high-contrast single bar generated by visage system (Cambridge Research Systems). The signal was amplified and thresholded (OmniPlex, Plexon). To ensure single-unit isolation, the waveforms of recorded units were further examined offline (Offline Sorter, Plexon). For each animal, 3-10 single units were recorded in each of the 4-6 vertical penetrations spaced evenly $(250 \mu \mathrm{m}$ intervals $)$ across mediolateral extent of V1 to map the monocular and binocular zones and avoid sampling bias. To analyze the electrophysiology data, normalized OD index of single neurons is computed by custom-made MATLAB program (The MathWorks) by peristimulus time histogram analysis of peak to baseline spiking activity in response to each eye: $\{[$ Peak (ipsi) - baseline (ipsi) $]-[$ Peak (contra) - baseline (contra) $]\} /\{[$ Peak (ipsi) - baseline (ipsi) $]+[$ Peak (contra) - baseline (contra) $]\}$. OD scores were converted from OD index using a 7 point classification scheme as follows: -1 to $-0.5=1 ;-0.5$ to $-0.3=2 ;-0.3$ to $-0.1=3 ;-0.1$ to $0.1=4 ; 0.1$ to $0.3=5 ; 0.3$ to $0.5=6$; and 0.5 to $1=7$. For each binocular zone, contralateral bias index $(\mathrm{CBI})$ is calculated according to the following formula: $[(n 1-n 7)+2 / 3(n 2-n 6)+1 / 3(n 3-n 5)+N] / 2 N$, where $N=$ total number of cells and $n x=$ number of cells corresponding to OD score of $x$. The changes in magnitude of each eye's responses by MD were represented as percentage change $((\mathrm{MD}-$ no $M D) /$ no $M D \times 100)$ using normalized firing rate of each neuron after $\mathrm{MD}$, and averaged normalized firing rates of no MD control. The firing rate of each unit was normalized as [Peak(contra) - baseline (contra)]/[Peak (contra) + baseline (contra)] for contralateral response, and [Peak (ipsi) - baseline (ipsi)]/[Peak (ipsi) + baseline (ipsi)] for ipsilateral response (Kravitz and Peoples, 2008). All AAV-injected mice were perfused after recordings and sectioned to examine the extent of AAV transduction by the presence of GFP signal in V1. Only mice that exhibited GFP signal in the recorded $\mathrm{V} 1$ area were included for the analysis of OD plasticity. A quantitative measurement of GFP intensity to correlate GFP expression with the magnitude of OD plasticity was hampered by the combinatorial damage of postrecorded V1 tissues due to multiple penetrations by the electrodes used for recording as well as the injection sites created by syringe needles used for AAV injections.

Statistics. All data are expressed as mean \pm SEM. Mean differences between two groups were determined using Student's $t$ test or MannWhitney $U$ test. For multiple-group comparisons, mean differences between groups were determined using a one-way ANOVA or KruskalWallis test, followed by Tukey or Dunn's post hoc tests when the main effect or interaction was significant at $p<0.05$. For electrophysiology experiments, $\chi^{2}$ test was used to measure OD shift, Student's $t$ test was used to compare CBI between two groups, and Kolmogorov-Smirnov (K-S) test was used to compare cumulative percentage of OD index across two groups. A minimum $p$ value of 0.05 was accepted as statistically significant throughout.

\section{Results \\ tPA activity elevates in adult V1 following MD in Lynx1 KO mice}

To examine the potential of adult V1 to elevate experiencedependent proteolytic activity when mice are raised in standard cages, we first measured tPA activity by an amidolytic assay from mouse V1 homogenates. Average age range of each experimental groups were 4.7-8.1 months (Fig. 1). We found no difference in tPA activity in adult WT V1 with and without $4 \mathrm{~d}$ of MD (WT adult no $\mathrm{MD}, n=12 ; 0.52 \pm 0.034$ vs WT adult $\mathrm{MD}, n=12$; $0.46 \pm 0.024, p=0.154$ Student's $t$ test; Figure $1 A$ ) consistent with previously reported findings (Mataga et al., 2004).

However, in adult Lynx1KO mice, we found a significant increase in tPA activity in $\mathrm{V} 1$ compared with its genotypic no MD (Lynx1 KO adult no MD, $n=18 ; 0.46 \pm 0.019$ vs Lynx1 KO adult MD, $n=16 ; 0.66 \pm 0.082, p<0.05$, Mann-Whitney $U$ test) and compared with its corresponding WT adult MD group (WT adult MD vs Lynx1 KO adult MD, $p<0.05$, Kruskal-Wallis test and post hoc Dunn's test; Fig. 1A).

To confirm the specificity of the proteolytic response, we then used the pharmacologic inhibitor tPA serpin (Serpini1) (Galliciotti and Sonderegger, 2006). The elevated tPA activity in adult Lynx1 KO mice with MD was significantly decreased with tPA serpin in ex vivo V1 homogenates (Lynx1 KO MD, $n=4 ; 0.61 \pm$ 0.079 vs Lynx $1 \mathrm{KO}+$ tPA Serpin, $n=4 ; 0.49 \pm 0.076, p<0.05$, paired Student's $t$ test; Figure $1 B$ ). Collectively, these findings suggest that the adult V1 has potential for elevating tPA activity after MD but is effectively limited by Lynx1 if mice are raised in standard cages.

\section{Stubby and thin spines decrease in a tPA-dependent manner in adult V1 of Lynx1 KO mice after MD}

Because MD-dependent elevation of tPA activity in juvenile V1 was shown to facilitate structural spine plasticity (Mataga et al., 2004; Oray et al., 2004), we asked whether tPA activity may affect dendritic spine plasticity in adult Lynx1 KO mice raised in standard cages. We visualized distal apical dendritic spines from layer 


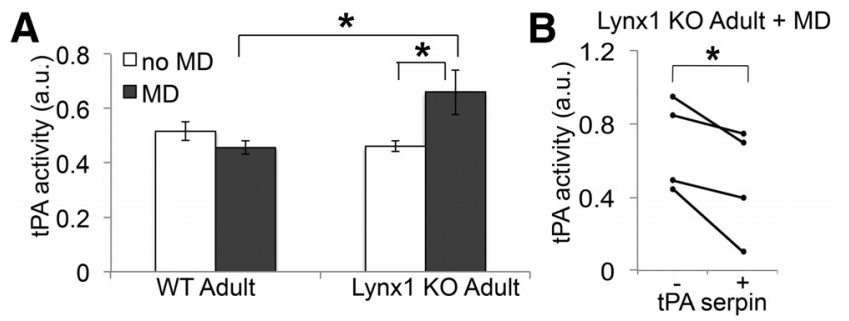

Figure 1. MD-dependent elevation of tPA proteolytic activity in adult V1 of Lynx1K0 mice. $A$, Measurement of tPA activity using amidolytic assay in right $\mathrm{V} 1$ homogenates from adult WT and Lynx1 $\mathrm{KO}$ mice with (dark gray) and without (white) $4 \mathrm{~d}$ of monocular deprivation of left eye (MD). $n=12-18$ mice. ${ }^{*} p<0.05$ (Kruskal-Wallis test with post hoc Dunn's test, and MannWhitney $U$ test). $\boldsymbol{B}$, tPA serpin, a known molecular inhibitor of tPA, was applied in ex vivo V1 homogenates from adult Lynx1 $\mathrm{KO}$ mice after $4 \mathrm{~d}$ (4D) of MD and tPA activity measured using amidolytic assay as above. $n=4$ mice ${ }^{*} p<0.05$ (paired Student's $t$ test). The range and the average age of mice for each subgroup were as follows: WT no MD: 2.6 - 6.8 months, average 6.1 months, WT MD: 2.6 - 6.8 months, average 4.7 months, Lynx 1 K0 no MD: 2.4 -13.1 months, average 8.1 months, and Lynx $1 \mathrm{KO}$ MD:2.3-11.0 months, average 5.9 months. As a recent study reported, no significant OD plasticity in WT mice $\sim$ P72 (age range P57-P80) (Stodieck et al., 2014), we also compared the PPA activity only with the mice older than P72 (excluding 2 mice each from KO noMD group and KO MD group who were younger than P72). In these sets of mice over P72, Lynx1K0 MD groups (14 mice) maintained a statistically significant increase in IPA activity compared with age-matched controls ( $p=0.031$ vs WT MD group, 12 mice; $p=0.020$ vs Lynx1 K0 no MD group, 16 mice, $t$ test). When only older adults ( $>$ P110) were compared, Lynx1KO MD groups (7 mice) also maintained statistically significant increase in tPA activity compared with age-matched controls ( $p=0.046$ vs WT MD group, 6 mice; $p=0.003$ vs Lynx 1 K0 no MD group, 12 mice, $t$ test). Only male mice were used in WT groups. In the Lynx1 K0 groups, a comparison between the two genders revealed no statistical difference in tPA activity within the Lynx $1 \mathrm{~K} 0$ no MD group (9 male, 6 female, excluding 3 mice with unidentified gender, $p=0.098, t$ test) or MD group ( 7 male and 9 female, $p=0.180, t$ test).

Table 1. Absolute spine density in adult V1 with and without MD ${ }^{a}$

\begin{tabular}{llllll}
\hline & $\begin{array}{l}\text { Total } \\
(\mathrm{sc} / \mu \mathrm{m})\end{array}$ & $\begin{array}{l}\text { Stubby } \\
(\mathrm{sc} / \mu \mathrm{m})\end{array}$ & $\begin{array}{l}\text { Thin } \\
(\mathrm{sc} / \mu \mathrm{m})\end{array}$ & $\begin{array}{l}\text { Mushroom } \\
(\mathrm{sc} / \mu \mathrm{m})\end{array}$ \\
\hline WT no MD & 5 & $1.48 \pm 0.040$ & $0.30 \pm 0.010$ & $0.68 \pm 0.046$ & $0.35 \pm 0.024$ \\
WT MD & 6 & $1.34 \pm 0.069$ & $0.30 \pm 0.007$ & $0.75 \pm 0.041$ & $0.30 \pm 0.026$ \\
Lynx1 K0 no MD & 5 & $1.35 \pm 0.032$ & $0.35 \pm 0.019$ & $0.72 \pm 0.036$ & $0.27 \pm 0.028$ \\
Lynx1 K0 MD & 6 & $0.97 \pm 0.047$ & $0.24 \pm 0.026$ & $0.53 \pm 0.056$ & $0.28 \pm 0.010$ \\
Lynx1-tPA DK0 no MD & 4 & $0.89 \pm 0.049$ & $0.23 \pm 0.002$ & $0.42 \pm 0.057$ & $0.25 \pm 0.015$ \\
Lynx1-tPA DK0 MD & 6 & $1.04 \pm 0.071$ & $0.26 \pm 0.013$ & $0.47 \pm 0.010$ & $0.30 \pm 0.003$
\end{tabular}

${ }^{a}$ Absolute spine density of total spines and three spine subtypes (stubby, thin, mushroom) in apical dendrites from V1 neurons with soma in layer II/III of WT, Lynx1 K0, and Lynx1-tPA DK0 mice with and without MD. Data are mean spine density (spine counts $[\mathrm{sc}] / \mu \mathrm{m}) \pm \operatorname{SEM}(\%)(n=4-6)$.

II/III neurons of adult V1 by injecting HSV-expressing GFP (Christoffel et al., 2011). Following $4 \mathrm{~d}$ of MD, the adult V1 was isolated and spine density was quantified using Neuron-Studio (see Materials and Methods) (Rodriguez et al., 2006, 2008; Christoffel et al., 2011; Dumitriu et al., 2011). Spines were subcategorized into three subtypes called mushroom, stubby, and thin spines based on previously established Neuron-Studio parameters (Table 1) (Rodriguez et al., 2006, 2008; Golden and Russo, 2012). As our dendritic spine labeling technique could not reliably measure spines in dendritic segments at set distances from the neuronal soma (Mataga et al., 2004), we focused on the most distal segments of apical dendrites to provide a uniform and unbiased analysis. Average age range of each experimental groups for spine analysis was 2.6-4.2 months (Fig. 2).

In adult V1 without visual manipulation, there was no statistical difference in total spine density between WT and Lynx1 KO mice (spine counts/ $\mu \mathrm{m}$ : WT no MD, $n=5 ; 1.48 \pm 0.040$ vs Lynx1 KO no MD, $n=5 ; 1.35 \pm 0.032, p>0.05$, one-way ANOVA) or the spine subtypes: stubby (WT no $\mathrm{MD}, n=5$; $0.30 \pm 0.010$ vs Lynx $1 \mathrm{KO}$ no MD, $n=5 ; 0.35 \pm 0.019, p>0.05$, one-way ANOVA), thin (WT no $\mathrm{MD}, n=5 ; 0.68 \pm 0.046$ vs Lynx1 KO no MD, $n=5 ; 0.72 \pm 0.036, p>0.05$, one-way ANOVA) or mushroom (WT no MD, $n=5 ; 0.35 \pm 0.024$ vs Lynx1 KO no MD, $n=5 ; 0.27 \pm 0.028, p>0.05$, one-way ANOVA; Table 1).

Next, to analyze to what extent Lynx1 removal impacts MDdependent dendritic spine plasticity, the spine density data of mice with MD (Table 1) was normalized to its no MD control of the same genotype and compared between genotypes (Fig. 2C). We found in V1 of adult Lynx1 KO mice a slight, albeit not statistically significant, MD-dependent decrease in total spine density (WT, $n=6 ;-9.71 \pm 4.654 \%$ vs Lynx1, $n=6 ;-24.91 \pm$ $2.352 \%, p=0.33$, one-way ANOVA and post hoc Tukey; Figure $2 B, C)$. When we further subcategorized these spines into three subtypes, we found that removal of Lynx1 led to significant MDdependent density reduction of the stubby spines (WT $=$ $-0.62 \pm 2.444 \%$ vs Lynx1 $\mathrm{KO}=-30.90 \pm 7.361 \%, p=0.005$, one-way ANOVA post hoc Tukey) and thin spines (WT $=9.72 \pm$ $6.025 \%$ vs Lynx1 KO $=-26.87 \pm 7.696 \%, p=0.004$, one-way ANOVA post hoc Tukey) in adult V1 following MD compared with its WT counterparts (Fig. $2 B, C$ ). In contrast, WT and Lynx1 $\mathrm{KO}$ mice show no statistically significant difference in MDdependent changes in mushroom spine density (WT $=-16.4 \pm$ $7.27 \%$ vs Lynx1 $=5.51 \pm 5.102 \%, p>0.05$, one-way ANOVA: Fig. $2 B, C)$. These results are consistent with previously published results on the role of stubby and thin spine subtypes in brain plasticity (Dumitriu et al., 2010; Christoffel et al., 2011).

To test the contribution of tPA activity on spine density changes in adult Lynx1KO mice, we next analyzed dendritic spines in mice lacking both tPA and Lynxl genes (Lynx1-tPA DKO). First, without visual deprivation, the Lynx1-tPA DKO mice have significantly less baseline density of total, thin, and stubby spine compared with their WT and Lynx1 KO counterparts $(p<0.0001, p<0.01$, and $p=0.0033$, one-way ANOVA post hoc Tukey), and less density of the mushroom spine subtypes compared with the WT group only ( $p=0.0453$, one-way ANOVA post hoc Tukey) (Table 1), suggesting some contribution of tPA to spine density at the baseline level independent of visual deprivation.

Next, to analyze the contribution of tPA activity on MDdependent spine density changes in adult Lynx1KO mice, the spine density data of mice with MD (Table 1) was normalized to its no MD control of the same genotype and compared between genotypes (Fig. 2C). Strikingly, the genetic removal of tPA in Lynx1 KO mice ablated the MD-dependent reduction of thin spines and stubby spines observed in Lynx $1 \mathrm{KO}$ mice (thin spines: Lynx1-tPA DKO, $n=6 ; 11.46 \pm 2.319 \%$ vs Lynx1 KO, $p=0.003$, one-way ANOVA post hoc Tukey, stubby spines: Lynx1-tPA DKO, $n=6$; $9.97 \pm 5.516 \%$, vs Lynx $1 \mathrm{KO}, p=0.0005$, one-way ANOVA, post hoc Tukey; Figure $2 B, C$ ). When we compared the changes of mushroom spine density of Lynx1-tPA DKO mice after MD with that of Lynx1 KO mice after MD, we find that, unlike stubby and thin spine subtypes, there was no significant difference in the change of mushroom spine density (Lynx1-tPA DKO, $n=6 ; 18.11 \pm 1.356 \%$ vs Lynx1KO, $p=0.37$, one-way ANOVA and post hoc Tukey; Fig. 2B,C). However, it should be noted that, in DKO mice, we also observed a significant MDdependent density increase only in mushroom spines but not in thin and stubby spines compared between $\mathrm{MD}$ and no $\mathrm{MD}$ groups (DKO no MD, $n=4 ; 0.25 \pm 0.015$ vs DKO MD, $n=6$; $0.30 \pm 0.003, p=0.03$, Student's $t$ test; Table 1$)$, or compared with MD-dependent change in WT mice ( $p=0.01$, one-way ANOVA and post hoc Tukey), suggesting an additional complex 
A

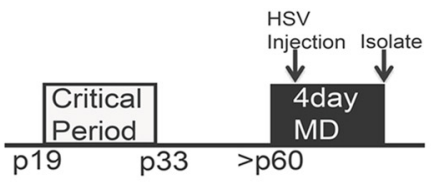

\section{B WT Adult + MD}

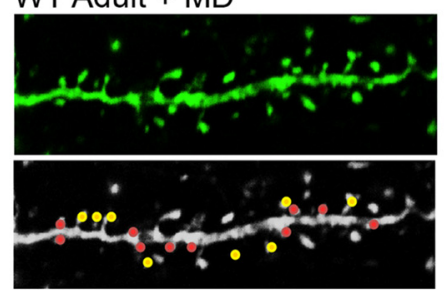

Lynx1 KO Adult + MD

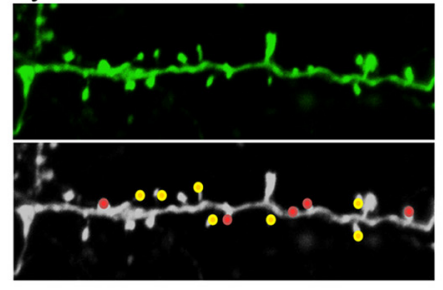

Lynx1-tPA DKO Adult +MD

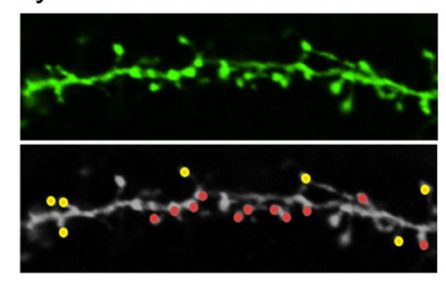

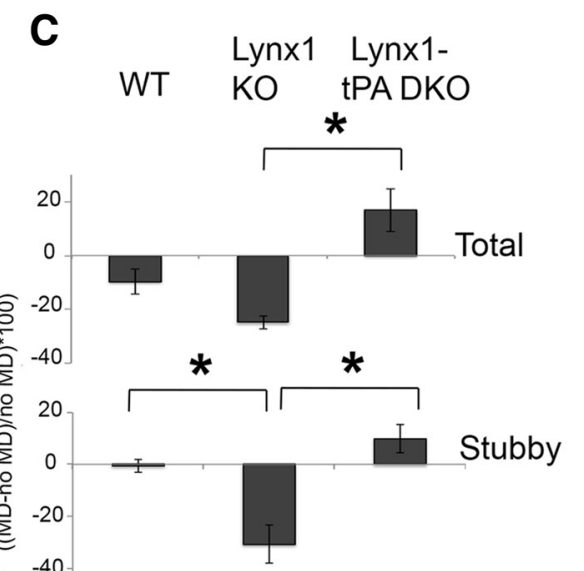

के

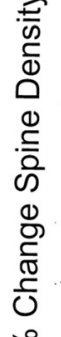

웅

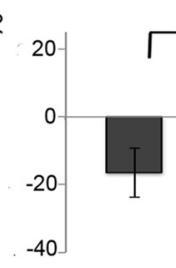

Figure 2. MD-dependent reduction of thin and stubby spine density in adult $\mathrm{V} 1$ of Lynx $1 \mathrm{~K} 0$ mice is dependent on TPA.A, Adult mice (> postnatal day 60) underwent HSV-GFP injection $1 \mathrm{~d}$ after MD. Four days after MD, adult V1 was isolated and processed for spine analysis. $\boldsymbol{B}$, Representative images of GFP-labeled dendritic spines (green) and corresponding gray schema below labeled with stubby (pink), thin (yellow), mushroom (nonlabeled white) spines in WT, Lynx1 K0, and Lynx1-tPA DK0 adult mice V1 after MD. C, Graphs showing MD-dependent changes of total spine density and densities of three subsets (stubby, thin, and mushroom) spines in adult V1 of WT, Lynx1 K0, and Lynx1-tPA DK0 mice. Each genotype was initially normalized to its no MD control of the same genotype, and all spine density graphs are represented as percentage change ((MD - no MD)/no MD $\times 100) ; n=4-6$. ${ }^{*} p<0.05$ (one-way ANOVA and post hoc Tukey test). The age range and the average of the mice for each subgroup were as follows: WT no MD: 3.8 - 4.3 months, average 4.2 months; WT MD: 3.6 - 4.1 months, average 3.9 months; Lynx1 K0 no MD: 2.8 -5.0 months, average 3.3 months; Lynx1 KO MD: 2.5-3.1 months, average 2.6 months; DKO no MD 2.1-4.3 months, average 3.3 months; and DKO MD 2.5 - 4.9 months, average 3.6 months. There was no statistically significant correlation between age and total spine density within each subset groups (Pearson correlation coefficient analysis: $R^{2}=0.426, p=0.160$ for WT no MD, $R^{2}=$ $0.036, p=0.719$ for WT no MD, $R^{2}=0.815, p=0.097$ for K0 no MD, $R^{2}=0.0572, p=0.761$ for KOMD, $R^{2}=0.985, p=0.078$ for DKO no MD, $R^{2}=0.110, p=0.586$ for DKO MD). Although the gender of mice was not controlled in this study (5 male for WT no MD, 3 male and 3 female for WT MD, 3 male and 2 female for KO no MD, 1 male and 5 female for KO MD, 3 male and 1 female for DKO no MD, 3 male and 3 female for DKO MD), the groups that had necessary number of mice for quantification ( $>3$ mice for each gender) did not show gender differences ( $p=0.719$ WT MD male vs female mice, $p=0.736$ for DKO MD male vs female group, $t$ test).

mechanism affecting the Lynx1-tPA DKO mushroom spine density that is distinct from the experience-dependent mechanism affecting the stubby and thin spine densities. This additional mechanism suggests a complex interaction between tPA, Lynx1, and experience, which requires exploration that lies beyond the scope of the current study. Collectively, our data demonstrate that removal of Lynx1 significantly decreases stubby and thin spines following $\mathrm{MD}$ in a tPA-dependent manner.

tPA is required for the elevated OD plasticity in adult Lynx1 KO mice

To examine the role of tPA activity on OD plasticity in adult Lynx1 KO mice when mice are raised in standard cages, we examined the neuronal spiking response of each eye in the V1 using

in vivo extracellular recordings following $4 \mathrm{~d}$ of MD in adult Lynx1-tPA DKO mice. Average age range of each experimental group for $\mathrm{OD}$ analysis was 2.8-6.4 months (Fig. 3).

We first confirmed our previous findings of extended OD plasticity in adult Lynx $1 K O$ mice with the upgraded singlecell sorting system (see Materials and Methods). Consistent with the previous study (Morishita et al., 2010), adult Lynx1 KO mice without MD ( $n=6$ mice, 82 cells, CBI $=0.6829)$ showed similar baseline OD to WT mice without MD $(n=11$ mice, 193 cells, $\mathrm{CBI}=0.6883)(\mathrm{OD}$ distribution: $p=0.73, \chi^{2}$ test, cumulative distribution of OD index: $p>0.81$, K-S test, CBI: $p=0.922$, Student's $t$ test). After $4 \mathrm{~d}$ of MD in adult Lynx1KO mice, there is a significant rightward OD shift toward the nondeprived eye (Lynx1 KO MD: $n=5$ mice, 87 cells, $\mathrm{CBI}=0.4674)$ compared with both WT MD ( $n=7$ mice, 86 cells, $\mathrm{CBI}=0.6744$. OD distribution: $p<$ $0.0001, \chi^{2}$ test, cumulative distribution of OD index: $p<0.0001$, K-S test, CBI: $p=$ 0.0025 Student's $t$ test) and Lynx1 KO no $\mathrm{MD}(n=6$ mice, 82 cells, $\mathrm{CBI}=0.6829$; OD distribution: $p<0.0001, \chi^{2}$ test, cumulative distribution of OD index: $p<$ 0.0001 , K-S test, CBI: $p=0.0031$, Student's $t$ test), confirming the extended $\mathrm{OD}$ plasticity in adult Lynx1KO mice (Morishita et al., 2010).

Genetic deletion of tPA itself did not result in a significant change in baseline OD distribution in Lynx1 KO mice without MD (Lynx1-tPA DKO mice with no MD: $n=5$ mice, 76 cells, CBI $=0.6425)$ compared with Lynx1 KO no MD ( $p>$ $0.26, \chi^{2}$ test), no shift in cumulative distribution of OD index for individual units $(p>0.63, \mathrm{~K}-\mathrm{S}$ test), and no difference in CBI ( $p=0.30$, Student's $t$ test). However, in contrast to adult Lynx1KO mice with $\mathrm{MD}, 4 \mathrm{~d}$ of MD in adult Lynx1-tPA DKO mice ( $n=5$ mice, 83 cells) showed no rightward shift toward the nondeprived eye in OD distribution $\left(p<0.0001, \chi^{2}\right.$ test; Fig. $3 B$ ), loss of shift in cumulative distribution of OD index for individual units ( $p<0.0001$, K-S test; Fig. $3 C$ ), and significant increase in CBI (CBI $=0.6205, p=0.032$, Student's $t$ test; Fig. $3 D$ ), suggesting that the deletion of tPA led to the loss of OD plasticity in adult Lynx1KO mice. Along the same lines, after $4 \mathrm{~d}$ of MD, adult Lynx 1-tPA DKO mice did not reveal any significant change in OD compared with its no MD genotypic counterpart (OD distribution, $p>0.29, \chi^{2}$ test, cumulative distribution of OD index: $p=0.7842$, K-S test, CBI: $p=0.86$, Student's $t$ test). Collectively, our results support a role for tPA in the OD shift in adult Lynx1 KO mice after MD.

Finally, as TPA is implicated in OD plasticity during the juvenile critical period (Mataga et al., 2002, 2004), we further examined to what extent elevated OD plasticity in adult Lynx1 $\mathrm{KO}$ mice 
reflects juvenile forms of plasticity. In juvenile mice, the OD shift after $4 \mathrm{~d} M D$ is mediated by a decrease of deprived contralateral eye response in V1 (Sato and Stryker, 2008; Espinosa and Stryker, 2012). Further quantification of our recording data revealed that the deprived contralateral eye response of adult Lynx $1 \mathrm{KO}$ mice is significantly decreased when their normalized firing rates were compared between $\mathrm{MD}$ and no MD groups (Lynx1 KO MD, $n=87$ cells; $0.48 \pm 0.0182$ vs Lynx1 KO no MD, $n=$ 82 cells; $0.61 \pm 0.0199, p<0.0001$, Student's $t$ test). Importantly, the MDdependent decrease in the deprived contralateral eye response in Lynx1 KO mice normalized to its no MD counterparts (Lynx 1 KO group, 87cells: $-22.77 \pm 3.17 \%$; Fig. $3 E$ ) was eliminated by the further genetic removal of tPA (Lynx $1 \mathrm{KO}$ group vs Lynx1-tPA DKO group, 83 cells; $15.25 \pm 3.46 \%, p<$ 0.0001 , Student's $t$ test; Fig. $3 E$ ). In contrast, there was no significant difference observed in the MD-dependent changes in response to the ipsilateral eye in V1 between the two genotypes (Lynx $1 \mathrm{KO}$ group: $7.61 \pm 3.660 \%$, 87 cells; vs Lynx1tPA DKO: $18.56 \pm 5.688 \%, 83$ cells; $p=$ 0.1036 , Student's $t$ test; Figure 3E). These results suggest that the removal of Lynx1 unmasks a tPA-dependent juvenile form of functional plasticity in adult $\mathrm{V} 1$ if mice are raised in standard cages. This is consistent with the structural plasticity data showing that the experience-dependent relative reduction in stubby and thin spine density in Lynx1 $\mathrm{KO}$ mice is also to some extent tPA-dependent (Fig. 2).

\section{Adult-specific inhibition of tPA activity can ablate OD plasticity in adult Lynx1KO mice}

As tPA KO mice were reported exhibit disrupted OD plasticity during critical period (Mataga et al., 2002), we aimed to rule out a confounding effect of developmental deletion of tPA in Lynx1-tPA DKO mice by reducing tPA activity only in the adult V1 with viral transduction of tPA serpin. Average age range of each experimental group was 5.0-6.8 months (Fig. 4). We first developed AAV expressing the tPA serpin bicistronically with GFP. To validate the virally induced tPA serpin overexpression, we measured the transduction of AAV, expression of tPA serpin, and tPA activity 3 weeks after injection in V1 of adult WT mice (Fig. $4 B-D$ ). The AAV transduction rate measured as the mean percentage of GFPpositive area in the binocular zone of $\mathrm{V} 1$ was $86.2 \pm 2.7 \%(n=10$ sections from 2 hemispheres) (Fig. $4 B$ ). Robust overexpression of tPA serpin in adult $V 1$ was evident by quantification of tPA serpin expression in AAV-tPA serpin and AAV-GFP injected mice using ISH (mean intensity of tPA serpin mRNA per GFP cells [AU]: AAV-GFP: $35.67 \pm 3.70, n=28$ cells; vs AVV-tPA Serpin $116.03 \pm 3.70, n=30$ cells; $p<0.001$ Student's $t$ test; Figure 4C) and overexpression of AAV-tPA-serpin in V1 significantly reduced tPA activity compared with AAV-GFP (AAV-GFP, $n=3$; vs AAV-tPA Serpin, $n=5 ; p=0.013$, Student's $t$ test; Figure $4 D$ ). After MD, compared with Lynx1 KO mice, Lynx1 KO mice expressing only the control GFP exhibited a similar rightward OD shift toward the nondeprived eye in the OD histogram (Lynx1 KO MD: $n=87$ cells from 5 mice vs Lynx1 KO + AAV-GFP MD: $n=89$ cells from 5 mice, $p=0.17, \chi^{2}$ test $)$, similar rightward shift in cumulative distribution of $\mathrm{OD}$ index for individual units (Lynx1 KO MD vs Lynx1 KO + AAV-GFP MD, $p=0.80$, K-S test) and a similar CBI (Lynx1 KO MD vs Lynx1 KO + AAV-GFP MD, CBI $=0.43, p=0.65$ Student's $t$ test).

In contrast to GFP viral overexpression, overexpression of tPA serpin in adult Lynx1 KO mice with MD induced no rightward OD shift toward the nondeprived eye in OD histogram (Lynx1 $\mathrm{KO}+$ AAV-GFP MD: $n=89$ cells from 5 mice vs Lynx $1 \mathrm{KO}+$ AAV-tPA Serpin MD: $n=97$ cells from 6 mice, $p=0.0005, \chi^{2}$ 
A

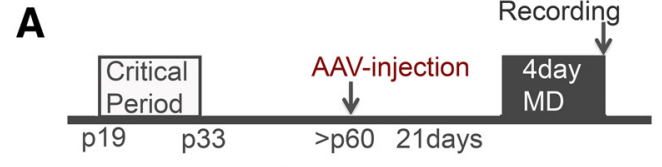

B

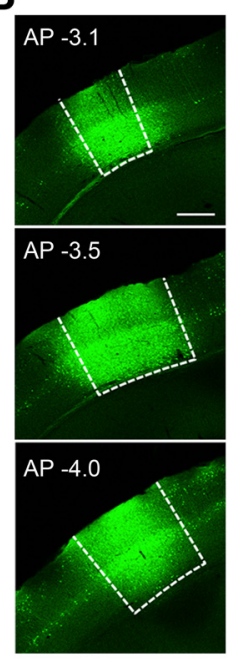

C

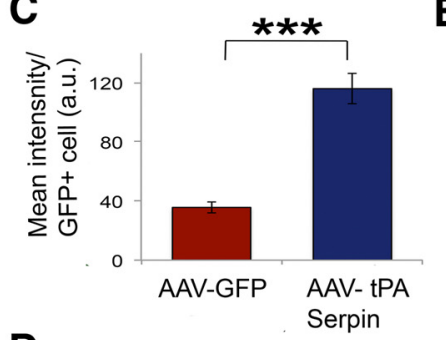

D

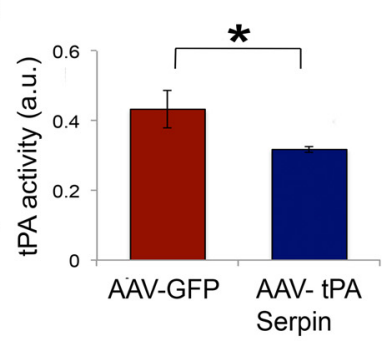

E
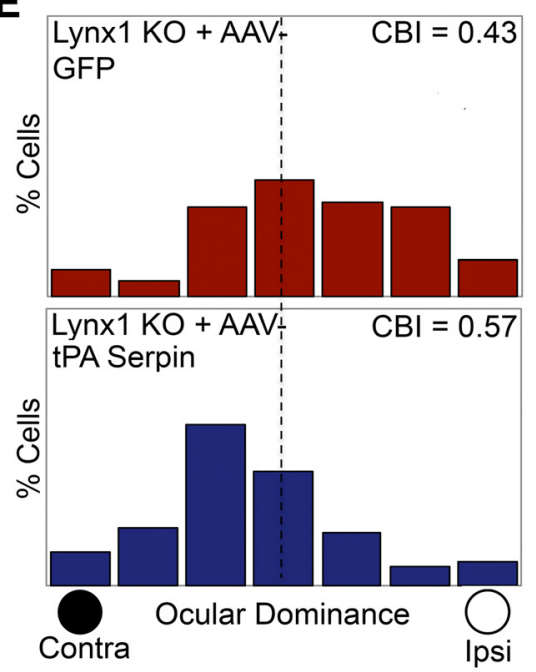

F

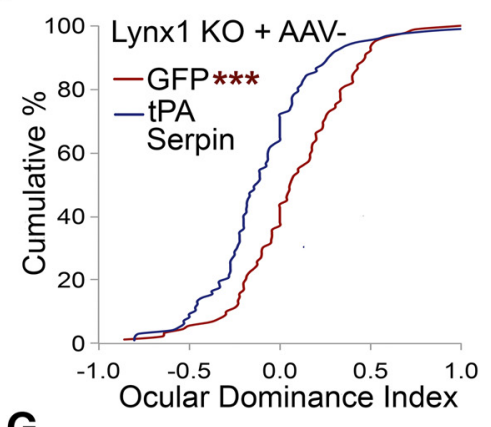

G

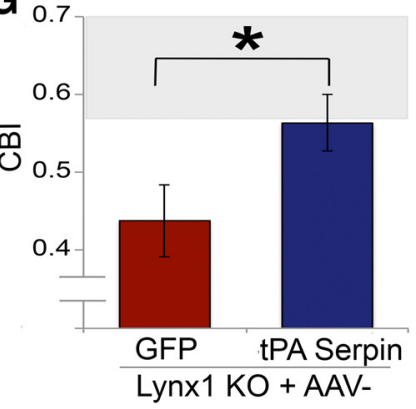

Figure 4. Adult specific inhibition of tPA ablates MD-dependent OD shift in Lynx $1 \mathrm{KO}$ mice. A, AAV-GFP or AAV-tPA serpin was injected in Lynx $1 \mathrm{~K} 0$ adult mice. MD was performed $21 \mathrm{~d}$ after brain injection, and in vivo electrophysiology $4 \mathrm{~d}$ after MD. $\boldsymbol{B}$, Representative images of the binocular zone of $\mathrm{V} 1$ from three different distances from bregma in anterior-posterior axis $(-3.1 \mathrm{~mm},-3.5$ $\mathrm{mm},-4.0 \mathrm{~mm}$ ) $21 \mathrm{~d}$ after AAV-tPA serpin injection showing bicistronically expressed GFP fluorophore. Binocular zone of V1 is outlined by dashed white-line based on Paxinos and Franklin (1997). Scale bar, $250 \mu \mathrm{m}$. C, Quantification of tPA serpin expression in AAV-tPA serpin and AAV-GFP-injected mice using ISH, data are represented as mean intensity of tPA serpin mRNA signal/GFP cell $(n=$ 30 cells for AAV-tPA seprin overexpression and $n=28$ cells for AAV-GFP overexpression). ${ }^{* * *} p<0.001$ (Student's $t$ test). D, Quantification of tPA activity after AAV-tPA Serpin or AAV-GFP injection in V1 using amidolytic assay $n=3-5 .{ }^{*} p<0.05$ (Student's $t$ test). $E$, Lynx $1 \mathrm{KO}+$ AAV-tPA serpin mice (blue histogram represents $n=6$ mice, 97 cells) showed no rightward shift in the $0 \mathrm{D}$ distribution after $4 \mathrm{dMD}$ in contrast to Lynx1K0 + AAV-GFP mice with MD (red histogram represents $n=5$ mice, 89 cells). ${ }^{* * *} p=0.0005$ ( $\chi^{2}$ test). $F$, Cumulative percentage of $0 D$ index confirms loss of OD shift after injection of tPA serpin compared with control AAV-GFP injection in Lynx1 KO mice with MD. ${ }^{* *} p<0.001$ (K-S test). G, Quantification of adult OD plasticity by CBI. CBI $=0.43$ in Lynx1 K0 + AAV-GFP and CBI $=0.57$ in Lynx1 K0 + tPA serpin. ${ }^{*} p<0.05$ (Student's $t$ test). Gray area represents CBI range in a nonplastic mouse. All mice were older than P110. The average age and age range of the mice for each subgroup are as follows: Lynx1 K0 AAV-GFP MD: 4.9-5.1 months, average 5.0 months, Lynx1 K0 AAV-NS MD: 5.3-7.9 months, average 6.8 months. Only females were used for recordings with AAV injections.

test; Fig. 4E), loss of shift in cumulative distribution of OD index for individual units (Lynx1 KO + AAV-GFP vs Lynx1 KO AAVtPA Serpin, $p=0.0004$, K-S test; Fig. $4 F$ ), and significant increase in CBI (Lynx1 KO + AAV-GFP, $n=5$; vs Lynx1 KO + AAV-tPA Serpin, $n=6$; CBI $=0.57, p=0.0005$, Student's $t$ test; Figure $4 G$ ). Along the same lines, after $4 \mathrm{~d}$ of MD, adult Lynx1 KO mice with AAV-tPA Serpin overexpression in V1 did not reveal any significant change in OD compared with its no MD genotypic counterpart $(n=3$ mice, 46 cells, $\mathrm{CBI}=0.59$ : OD distribution, $p>$ 0.75, $\chi^{2}$ test, cumulative distribution of OD index: $p>0.98, \mathrm{~K}-\mathrm{S}$ test, CBI: $p>0.60$, Student's $t$ test). Although these experiments using Lynx1KO mice cannot fully rule out the confounding effect of developmental deletion of Lynx1, we expect such an effect is minimal because: (1) the OD plasticity of Lynx1KO mice during critical period is normal in contrast to tPA KO mice that have disrupted OD plasticity during critical period; and (2) an elevated OD plasticity in adult Lynx1KO mice can be blocked by an acute application of nAChR antagonists (Morishita et al., 2010). Our separate parallel study is expected to draw a conclusion by testing if the adult specific knockdown of Lynx1 expression in WT V1 is sufficient to phenocopy an elevated OD plasticity in adult Lynx1KO mice (M.S., P.B., M.P.D., H.M.). Collectively, our data support an adult specific role of tPA activity in OD plasticity in Lynx1 KO mice after MD when mice are raised in standard cages.

\section{Discussion}

The aim of our study was to understand why experiencedependent tPA elevation does not occur in the adult mice brain older than 2 months if raised in standard cage. We demonstrated that removal of Lynx1, one of the negative regulators of plasticity, can unmask experience-dependent tPA elevation in adult brain. This sensory-dependent proteolytic elevation facilitated dendritic spine reduction and OD plasticity in adult V1. Our work demonstrates, for the first time, that adult brain retains the intrinsic capacity to elevate tPA in an experience-dependent manner even after closure of the classical critical period for OD plasticity. However, unlike juvenile brain, the adult brain of standard cage-raised mice requires a two hit approach (sensory deprivation and removal of negative regulators such as Lynx1) to unmask plasticity.

tPA and Lynx1 then may become promising molecular targets for restoring adult plasticity. Recently, multiple interventions were reported to activate and/or preserve plasticity in adult V1, including dark rearing (He et al., 2006, 2007; Duffy and Mitchell, 2013; Stodieck et al., 2014), environmental enrichment (Sale et al., 2007; Greifzu et al., 2014), visual stimulation (Matthies et al., 2013), sensory-motor interaction (Kaneko and Stryker, 2014), voluntary physical exercise (Kalogeraki et al., 2014), and social experience (Balog et al., 2014) in addition to pharmacological interventions (Putignano et al., 2007; Maya Vetencourt et al., 2008; Morishita et al., 2010; Nabel and Morishita, 2013). Importantly, these interventions seem to have differential specificity and magnitude (Hübener and Bonhoeffer, 2014). Although some underlying molecular mechanisms have been identified, such as reduced intracortical inhibition (Greifzu et al., 2014; Stodieck et 
al., 2014), disinhibitory cortical circuit (Fu et al., 2015), and serotonin (Matthies et al., 2013), the contribution of tPA or Lynx1 has never been examined. Our study suggests that tPA and Lynx1 may potentially be a new candidate mechanism for interventions that may activate plasticity in adult brain. As the removal of Lynx1 unmasks a juvenile form of plasticity (Figs. 2, 3), tPALynx1 may be particularly relevant to the interventions that were shown to restore juvenile forms of plasticity, such as environmental enrichment (Greifzu et al., 2014) and voluntary physical exercise (Kalogeraki et al., 2014). Thus, it would be interesting to examine whether the expression of tPA proteolytic activity can remain elevated upon $\mathrm{MD}$ in these rearing conditions in future studies. More conceptually, the fact that some environment can lead to juvenile level of plasticity in the adult raises a possibility that limited plasticity in the adult mice raised in standard laboratory cages may not necessarily reflect the normal physiological change, but rather a special case in an impoverished environment. In future, it is important to conduct the experiments in an environment as close as possible to a natural environment to assess the "true" contribution of Lynx1-tPA system for adult plasticity.

Age is another important factor that can impact the OD plasticity in adult mice. A recent study showed that young adults $(<$ P110) but not full adults $(>$ P110) exhibited an adult form of OD plasticity after $7 \mathrm{~d}$ of MD (Lehmann and Löwel, 2008). It should be noted, though, that such an age-dependent effect critically depends on the length of MD. Importantly, shorter $4 \mathrm{~d}$ of $\mathrm{MD}$ does not induce OD plasticity in young adult mice well under the age of P110 to P72 (age range P58-P80) (Stodieck et al., 2014), P80 (Huang et al., 2015), and P84-P91 (Sato and Stryker, 2008). In our study, the average age of each experimental group was older than P72, and we similarly did not detect significant difference in OD plasticity by $4 \mathrm{~d}$ of MD between adult WT mice subgroups younger versus older than P72 or P110 (Fig. 3), suggesting that our study is likely not sensitive enough to detect age-dependent changes of OD plasticity, if any, among adults. Indeed, for both the tPA activity and OD plasticity, when data were compared only with the mice older than P72 or P110, Lynx1KO MD groups maintained statistically significant increase in tPA activity (Fig. 1) and OD plasticity (Fig. 3) compared with age-matched controls. We also did not detect any statistically significant correlation between age and total spine density within each subset groups (Fig. 2). Gender can also potentially impact OD plasticity in the adults. A recent imaging study reported that fully adult female mice can exhibit OD plasticity when pairhoused in standard cage during $4 \mathrm{~d}$ of MD (Balog et al., 2014), raising a possibility that the female mice can be more plastic in certain rearing conditions. Although our study did not control for gender across groups, no difference in gender-dependent effect on plasticity was detected for any subgroup that had enough mice number for quantification (detail in figure legends). In addition, when we compared only male mice, we still detected statistically significant increase of OD plasticity in Lynx1KO MD group compared with WT MD group or DKO MD group (Fig. 3). Overall, our study did not detect significant age and gender effect in any of our measurements, and is least likely confounded by these factors. Nonetheless, to fully examine the age effect and gender effect that can confound the results, an extensive study using both 4 and $7 \mathrm{~d}$ of $\mathrm{MD}$ is required for all measurements in future studies as it was done for the hemodynamic imaging (Lehmann and Löwel, 2008).

Our study also provides the novel mechanisms of plasticity limited by Lynx1 in adult brain. Lynx1 acts as an inhibitor of the nicotinic Acetylcholine receptor (Miwa et al., 1999, 2006, 2011; Ibañez-Tallon et al., 2002; Picciotto et al., 2012). A previous study showed that its removal allows for increased nicotinic signaling and functional adult brain plasticity (Morishita et al., 2010). But the role of Lynx1 in structural plasticity remained unclear. The current study indicates that dendritic spine changes are important contributors to experience-dependent adult brain plasticity in the absence of Lynx1. Specifically, we found that MD results in reduction of distal apical dendritic spines from V1 neurons in layer II/III in adult Lynx1 KO mice, a pattern very similar to the MD-dependent spine plasticity during the juvenile period (Mataga et al., 2004). Consistent with the structural mechanisms, our in vivo electrophysiological recordings also identified that the functional OD plasticity in adult Lynx1 KO mice is mediated by a decrease in the response of the deprived contralateral eye in V1, a signature of juvenile-like plasticity. Our structural and functional studies collectively suggest that the removal of Lynx1 can unmask juvenile form of plasticity, consistent with the elevation of tPA activity. Interestingly, the deletion of postsynaptic density protein-95 (PSD-95) also induces juvenile form of OD plasticity in adult mouse V1 (Huang et al., 2015). As the PSD-95 KO mice accompany failed maturation of silent synapses, it would be interesting to test whether Lynx1-tPA system similarly regulates the maturation of silent synapses as well as to examine whether PSD-95 regulates dendritic spine plasticity as Lynx1 does.

Elucidating the cellular and molecular basis of the Lynx1-tPA interaction will be an important area of future exploration. Although our study focused on the role of Lynx1 to regulate tPA activity, it is possible that other negative regulators, such as chondroitin sulfate proteoglycans (CSPGs), the myelin inhibitor protein, Nogo66 receptor 1 (NgR1), Paired-immunoglobulin-like receptor B (PirB), and Cartilage link protein (Crtl1) (Pizzorusso et al., 2002; McGee et al., 2005; Syken et al., 2006; Carulli et al., 2010) may also play a role in limiting experience-dependent tPA activity. Future studies should help to distinguish whether multiple negative regulators act on multiple experience-dependent permissive factors (Maya-Vetencourt et al., 2012; Spolidoro et al., 2012) or whether tPA acts as a molecular hub gated by multiple negative regulators. Determination of the targets of tPA in the plasticity pathway will be also important to draw conclusions about the neural mechanisms. Mataga and colleagues (Mataga et al., 2002, 2004) previously discussed BDNF, NCAM, laminin, and CSPGs as potential molecular and structural targets of tPA in juvenile brain. Our study focused on the role of tPA in the adult brain. Unlike juvenile brain, the extracellular matrix of the adult brain is rich in CSPGs (Pizzorusso et al., 2002; Cabungcal et al., 2013; de Vivo et al., 2013). We previously showed that tPA can degrade CSPGs and allow for enhanced recovery in adult CNS injury models (Wu et al., 2000; Nolin et al., 2008; Bukhari et al., 2011). Our work demonstrated that tPA and its substrate plasminogen bind to the core proteins of CSPGs, which function as a scaffold to accelerate the tPA-driven conversion of plasminogen to plasmin. Once generated, plasmin then degrades the CSPG scaffold protein. Whether similar or distinct mechanisms are involved in V1 plasticity model is an important future question.

Our work indicates that the adult brain retains intrinsic capacity to elevate permissive tPA activity but is effectively masked by Lynx1 to limit cortical plasticity. Removal of Lynx1 can allow for elevation of experience-dependent proteolytic activity and subsequent structural and functional plasticity. These mechanistic insights will provide novel therapeutic targets for adult brain disorders. 


\section{References}

Balog J, Matthies U, Naumann L, Voget M, Winter C, Lehmann K (2014) Social experience modulates ocular dominance plasticity differentially in adult male and female mice. Neuroimage 103:454-461. CrossRef Medline

Bavelier D, Levi DM, Li RW, Dan Y, Hensch TK (2010) Removing brakes on adult brain plasticity: from molecular to behavioral interventions. J Neurosci 30:14964-14971. CrossRef Medline

Bukhari N, Torres L, Robinson JK, Tsirka SE (2011) Axonal regrowth after spinal cord injury via chondroitinase and the tissue plasminogen activator (tPA)/plasmin system. J Neurosci 31:14931-14943. CrossRef Medline

Cabungcal JH, Steullet P, Morishita H, Kraftsik R, Cuenod M, Hensch TK, Do KQ (2013) Perineuronal nets protect fast-spiking interneurons against oxidative stress. Proc Natl Acad Sci U S A 110:9130-9135. CrossRef Medline

Carmeliet P, Schoonjans L, Kieckens L, Ream B, Degen J, Bronson R, De Vos R, van den Oord JJ, Collen D, Mulligan RC (1994) Physiological consequences of loss of plasminogen activator gene function in mice. Nature 368:419-424. CrossRef Medline

Carulli D, Pizzorusso T, Kwok JC, Putignano E, Poli A, Forostyak S, Andrews MR, Deepa SS, Glant TT, Fawcett JW (2010) Animals lacking link protein have attenuated perineuronal nets and persistent plasticity. Brain 133:2331-2347. CrossRef Medline

Christoffel DJ, Golden SA, Dumitriu D, Robison AJ, Janssen WG, Ahn HF, Krishnan V, Reyes CM, Han MH, Ables JL, Eisch AJ, Dietz DM, Ferguson D, Neve RL, Greengard P, Kim Y, Morrison JH, Russo SJ (2011) Ikap$\mathrm{paB}$ kinase regulates social defeat stress-induced synaptic and behavioral plasticity. J Neurosci 31:314-321. CrossRef Medline

de Vivo L, Landi S, Panniello M, Baroncelli L, Chierzi S, Mariotti L, Spolidoro M, Pizzorusso T, Maffei L, Ratto GM (2013) Extracellular matrix inhibits structural and functional plasticity of dendritic spines in the adult visual cortex. Nat Commun 4:1484. CrossRef Medline

Duffy KR, Mitchell DE (2013) Darkness alters maturation of visual cortex and promotes fast recovery from monocular deprivation. Curr Biol 23: 382-386. CrossRef Medline

Dumitriu D, Hao J, Hara Y, Kaufmann J, Janssen WG, Lou W, Rapp PR, Morrison JH (2010) Selective changes in thin spine density and morphology in monkey prefrontal cortex correlate with aging-related cognitive impairment. J Neurosci 30:7507-7515. CrossRef Medline

Dumitriu D, Rodriguez A, Morrison JH (2011) High-throughput, detailed, cell-specific neuroanatomy of dendritic spines using microinjection and confocal microscopy. Nat Protoc 6:1391-1411. CrossRef Medline

Espinosa JS, Stryker MP (2012) Development and plasticity of the primary visual cortex. Neuron 75:230-249. CrossRef Medline

Fagiolini M, Pizzorusso T, Berardi N, Domenici L, Maffei L (1994) Functional postnatal development of the rat primary visual cortex and the role of visual experience: dark rearing and monocular deprivation. Vision Res 34:709-720. CrossRef Medline

Fu Y, Kaneko M, Tang Y, Alvarez-Buylla A, Stryker MP (2015) A cortical disinhibitory circuit for enhancing adult plasticity. eLife 4:e05558. CrossRef Medline

Galliciotti G, Sonderegger P (2006) Neuroserpin. Front Biosci 11:33-45. CrossRef Medline

Golden SA, Russo SJ (2012) Mechanisms of psychostimulant-induced structural plasticity. Cold Spring Harb Perspect Med 2:a011957. CrossRef Medline

Gordon JA, Stryker MP (1996) Experience-dependent plasticity of binocular responses in the primary visual cortex of the mouse. J Neurosci 16: 3274-3286. Medline

Greifzu F, Pielecka-Fortuna J, Kalogeraki E, Krempler K, Favaro PD, Schlüter OM, Löwel S (2014) Environmental enrichment extends ocular dominance plasticity into adulthood and protects from stroke-induced impairments of plasticity. Proc Natl Acad Sci U S A 111:1150-1155. CrossRef Medline

He HY, Hodos W, Quinlan EM (2006) Visual deprivation reactivates rapid ocular dominance plasticity in adult visual cortex. J Neurosci 26:29512955. CrossRef Medline

He HY, Ray B, Dennis K, Quinlan EM (2007) Experience-dependent recovery of vision following chronic deprivation amblyopia. Nat Neurosci 10: 1134-1136. CrossRef Medline

Hensch TK (2004) Critical period regulation. Annu Rev Neurosci 27:549579. CrossRef Medline

Huang X, Stodieck SK, Goetze B, Cui L, Wong MH, Wenzel C, Hosang L,
Dong Y, Löwel S, Schlüter OM (2015) Progressive maturation of silent synapses governs the duration of a critical period. Proc Natl Acad Sci U S A 112:E3131-3140. CrossRef Medline

Hübener M, Bonhoeffer T (2014) Neuronal plasticity: beyond the critical period. Cell 159:727-737. CrossRef Medline

Ibañez-Tallon I, Miwa JM, Wang HL, Adams NC, Crabtree GW, Sine SM, Heintz N (2002) Novel modulation of neuronal nicotinic acetylcholine receptors by association with the endogenous prototoxin lynxl. Neuron 33:893-903. CrossRef Medline

Kalogeraki E, Greifzu F, Haack F, Löwel S (2014) Voluntary physical exercise promotes ocular dominance plasticity in adult mouse primary visual cortex. J Neurosci 34:15476-15481. CrossRef Medline

Kaneko M, Stryker MP (2014) Sensory experience during locomotion promotes recovery of function in adult visual cortex. eLife 3:e02798. CrossRef Medline

Knudsen EI (2004) Sensitive periods in the development of the brain and behavior. J Cogn Neurosci 16:1412-1425. CrossRef Medline

Kravitz AV, Peoples LL (2008) Background firing rates of orbitofrontal neurons reflect specific characteristics of operant sessions and modulate phasic responses to reward-associated cues and behavior. J Neurosci 28: 1009-1018. CrossRef Medline

Lehmann K, Löwel S (2008) Age-dependent ocular dominance plasticity in adult mice. PLoS One 3:e3120. CrossRef Medline

Levelt CN, Hübener M (2012) Critical-period plasticity in the visual cortex. Annu Rev Neurosci 35:309-330. CrossRef Medline

Mataga N, Nagai N, Hensch TK (2002) Permissive proteolytic activity for visual cortical plasticity. Proc Natl Acad Sci US A 99:7717-7721. CrossRef Medline

Mataga N, Mizuguchi Y, Hensch TK (2004) Experience-dependent pruning of dendritic spines in visual cortex by tissue plasminogen activator. Neuron 44:1031-1041. CrossRef Medline

Matthies U, Balog J, Lehmann K (2013) Temporally coherent visual stimuli boost ocular dominance plasticity. J Neurosci 33:11774-11778. CrossRef Medline

Maya Vetencourt JF, Sale A, Viegi A, Baroncelli L, De Pasquale R, O'Leary OF, Castrén E, Maffei L (2008) The antidepressant fluoxetine restores plasticity in the adult visual cortex. Science 320:385-388. CrossRef Medline

Maya-Vetencourt JF, Tiraboschi E, Greco D, Restani L, Cerri C, Auvinen P, Maffei L, Castrén E (2012) Experience-dependent expression of NPAS4 regulates plasticity in adult visual cortex. J Physiol 590:4777-4787. CrossRef Medline

McGee AW, Yang Y, Fischer QS, Daw NW, Strittmatter SM (2005) Experience-driven plasticity of visual cortex limited by myelin and Nogo receptor. Science 309:2222-2226. CrossRef Medline

Mitchell DE, Sengpiel F (2009) Neural mechanisms of recovery following early visual deprivation. Philos Trans R Soc Lond B Biol Sci 364:383-398. CrossRef Medline

Miwa JM, Ibañez-Tallon I, Crabtree GW, Sánchez R, Sali A, Role LW, Heintz N (1999) lynxl, an endogenous toxin-like modulator of nicotinic acetylcholine receptors in the mammalian CNS. Neuron 23:105-114. CrossRef Medline

Miwa JM, Stevens TR, King SL, Caldarone BJ, Ibañez-Tallon I, Xiao C, Fitzsimonds RM, Pavlides C, Lester HA, Picciotto MR, Heintz N (2006) The prototoxin lynx 1 acts on nicotinic acetylcholine receptors to balance neuronal activity and survival in vivo. Neuron 51:587-600. CrossRef Medline

Miwa JM, Freedman R, Lester HA (2011) Neural systems governed by nicotinic acetylcholine receptors: emerging hypotheses. Neuron 70:20-33. CrossRef Medline

Morishita H, Hensch TK (2008) Critical period revisited: impact on vision. Curr Opin Neurobiol 18:101-107. CrossRef Medline

Morishita H, Miwa JM, Heintz N, Hensch TK (2010) Lynx1, a cholinergic brake, limits plasticity in adult visual cortex. Science 330:1238-1240. CrossRef Medline

Nabel EM, Morishita H (2013) Regulating critical period plasticity: insight from the visual system to fear circuitry for therapeutic interventions. Front Psychiatry 4:146. CrossRef Medline

Nolin WB, Emmetsberger J, Bukhari N, Zhang Y, Levine JM, Tsirka SE (2008) tPA-mediated generation of plasmin is catalyzed by the proteoglycan NG2. Glia 56:177-189. CrossRef Medline

Oray S, Majewska A, Sur M (2004) Dendritic spine dynamics are regulated by monocular deprivation and extracellular matrix degradation. Neuron 44:1021-1030. CrossRef Medline 
Paxinos G, Franklin KBJ (1997) The mouse brain in stereotaxic coordinates. San Diego: Academic.

Picciotto MR, Higley MJ, Mineur YS (2012) Acetylcholine as a neuromodulator: cholinergic signaling shapes nervous system function and behavior. Neuron 76:116-129. CrossRef Medline

Pizzorusso T, Medini P, Berardi N, Chierzi S, Fawcett JW, Maffei L (2002) Reactivation of ocular dominance plasticity in the adult visual cortex. Science 298:1248-1251. CrossRef Medline

Putignano E, Lonetti G, Cancedda L, Ratto G, Costa M, Maffei L, Pizzorusso T (2007) Developmental downregulation of histone posttranslational modifications regulates visual cortical plasticity. Neuron 53:747-759. CrossRef Medline

Rodriguez A, Ehlenberger DB, Hof PR, Wearne SL (2006) Rayburst sampling, an algorithm for automated three-dimensional shape analysis from laser scanning microscopy images. Nat Protoc 1:2152-2161. CrossRef Medline

Rodriguez A, Ehlenberger DB, Dickstein DL, Hof PR, Wearne SL (2008) Automated three-dimensional detection and shape classification of dendritic spines from fluorescence microscopy images. PLoS One 3:e1997. CrossRef Medline

Sale A, Maya Vetencourt JF, Medini P, Cenni MC, Baroncelli L, De Pasquale R, Maffei L (2007) Environmental enrichment in adulthood promotes amblyopia recovery through a reduction of intracortical inhibition. Nat Neurosci 10:679-681. CrossRef Medline

Sato M, Stryker MP (2008) Distinctive features of adult ocular dominance plasticity. J Neurosci 28:10278-10286. CrossRef Medline

Spolidoro M, Putignano E, Munafò C, Maffei L, Pizzorusso T (2012) Inhibition of matrix metalloproteinases prevents the potentiation of nondeprived-eye responses after monocular deprivation in juvenile rats. Cereb Cortex 22:725-734. CrossRef Medline

Stodieck SK, Greifzu F, Goetze B, Schmidt KF, Löwel S (2014) Brief dark exposure restored ocular dominance plasticity in aging mice and after a cortical stroke. Exp Gerontol 60:1-11. CrossRef Medline

Syken J, Grandpre T, Kanold PO, Shatz CJ (2006) PirB restricts oculardominance plasticity in visual cortex. Science 313:1795-1800. CrossRef Medline

Wiesel TN (1982) Postnatal development of the visual cortex and the influence of environment. Nature 299:583-591. CrossRef Medline

Wu YP, Siao CJ, Lu W, Sung TC, Frohman MA, Milev P, Bugge TH, Degen JL, Levine JM, Margolis RU, Tsirka SE (2000) The tissue plasminogen activator (tPA)/plasmin extracellular proteolytic system regulates seizureinduced hippocampal mossy fiber outgrowth through a proteoglycan substrate. J Cell Biol 148:1295-1304. CrossRef Medline 